\title{
IN SPITE OF MEDICAL HELP: THE PUZZLE OF AN EIGHTEENTH-CENTURY PRIME MINISTER'S ILLNESS
}

\author{
by
}

\section{MARJORIE BLOY*}

Charles Watson Wentworth, second Marquis of Rockingham, died suddenly and unexpectedly on 1 July 1782 , when he was only 52 years old. He had suffered-or enjoyed - ill health all his life but in 1782 appeared to be no worse than he had ever been. His death in London terminated his second period of office as Prime Minister, to which he had been appointed only 14 weeks earlier. In May he had reported to the Duke of Portland that he had "for some weeks past undergone much Pain and much inconvenience from something similar to my old Complaint in my Side and Stomach" but that he felt much better than he had. ${ }^{1}$ By 17 June he was recovering from both influenza and his "old complaint". 2 On 1 July he died and on the 20 th he was interred in York Minster.

The first recorded bout of illness suffered by the marquis, then Lord Higham, was in July 1741 when the 11-year-old was "a little indisposed, something Feaverish I guess it proceeds from Worms and will Soon be removed". ${ }^{3} \mathrm{He}$ also had a rash and it was thought that the cause of the problem was that the boy had overheated himself. ${ }^{4}$ He was still ill at the beginning of August: he had been "much out of order" for a long time but had been recommended to take warm baths by Dr Wilmot and Mr Ranby when they were consulted in London. ${ }^{5}$ Charles's aunt, Lady Isabella Finch, was sure that the baths "and other Things They'll prescribe will in a short Time entirely Cure his Complaints w[hic]h neither of Them thought proceed from any dangerous Causes". 6 In spite of Lady Isabella's hopes, Charles did not greatly improve, even though his mother believed that he continued mending every day. The main reason that Higham and his mother had gone to London to consult $\mathrm{Dr}$ Wilmot and $\mathrm{Mr}$

*Marjorie Bloy, Ph.D., 18 Farm View Road, Kimberworth, Rotherham, S. Yorks. S61 2BA.

The Rockingham Papers are in the holdings of the Wentworth Woodhouse Muniments at Sheffield City Archives Department, Sheffield City Library. I am grateful to Dr R. S. Morton for his advice and help with the diagnostic sections of this essay.

${ }^{1}$ WWM, R1-2094. Rockingham to Portland, 25 May 1782.

${ }^{2}$ WWM, R1-2094. Rockingham to Charlemont, 17 June 1782.

${ }^{3}$ WWM, M8-25. Malton to Nottingham, after 16 June 1741.

${ }^{4}$ WWM, M8-26. Lady Finch to Lady Malton, 30 July 1741.

${ }^{5}$ WWM, M8-28. Winchelsea to Malton, 7 August 1741.

${ }^{6}$ WWM, M8-29. Lady Finch to Malton, 7 August 1741. 


\section{An eighteenth-century Prime Minister's illness}

Ranby was his mother's concern about a "swelling in a certain part which was larger than when we left Wentworth". The doctors hoped that it would burst outwards "which they assure me will be the safest way and give the poor Monkey but very little pain"? 7

On 20 August Lord Winchelsea, Higham's uncle, surprised to see the boy so well and brisk, hoped that Charles was "now safe from this complaint"- the same one from which he had suffered in 1738-39-but thought that he would never be safe "if he continues the practice of overheating himself and then drinking Cold Water". He said that Charles was of a "pretty healthy strong Constitution";8 Lady Malton was not so sure. The same day she wrote a progress report to her husband saying that Charles's swelling continued to grow, as did the pain "in that part (but not the lease [sic] trouble in making Water or going to Stool) \& less Fever than c[oul]d be imagined where Matter is as they now imagine certainly gathering and must end in an operation". In spite of it all, Charles was in fine spirits. ${ }^{9}$ Lady Malton dosed the boy with cinchona bark, which removed the pains in his legs and reduced his fever, and she was convinced that they would soon have "a clear Stage to act in a proper manner a[bou]t his other Complaints w[hic]h the Learned assure me are to be conquered also". "Charles was soon allowed to eat meat and Mr Ranby still assured her that the swelling would break outwards. ${ }^{11}$ Three days later he decided to lance it, even though Dr Bourne disagreed. The boy's mother was puzzled because the swelling "sometimes pushes forward very fast then retires a little" but the doctor and Ranby seemed happy with his condition. ${ }^{12}$ At this point the letters cease, presumably because Malton arrived in London with his daughters, to have them inoculated against smallpox, but a later letter states that surgery to open the swelling was not undertaken. ${ }^{13}$

By the end of October the correspondence had recommenced. Charles was ill again. He was just the same as when he left Kensington, so John Bourne had bled him and the child had started on Sir Edward Hulse's prescription, unfortunately not defined in the letter, but which was apparently as bad as the last one, if not worse. Lady Malton thought that "with such a State of Blood the Continuation of Health cannot be expected" but was hopeful that the "Cinnabar may prove a more Efficacious remedie than any than has been tryed yet". 14 That night she applied "a Blister . . . without the least Symptom or tendency to anything like Strangury". He bore the treatment well, as he had done three years previously, and it seemed so successful that Lady Malton was "determined to keep it running full as long as I did last time by the help of John Borne [sic] with much ease to the Dear Child". ${ }^{15}$ She

\footnotetext{
${ }^{7}$ WWM, M7-51. Lady to Lord Malton, 18 August 1741.

${ }^{8}$ WWM, M2-84. Winchelsea to Malton, 20 August 1741.

${ }^{9}$ WWM, M7-52. Lady to Lord Malton, 20 August 1741.

10 WWM, M7-53. Lady to Lord Malton, 25 August 1741.

11 WWM, M7-54. Lady to Lord Malton, 29 August 1741.

12 WWM, M7-55. Lady to Lord Malton, 1 September 1741.

13 WWM, R170-20. Nicolò Scanagati of Padua, 20 July 1750. I am grateful to Fr John McMahon and Dr Stephen Bemrose for their translations of this letter.

14 WWM, M7-14. Lady to Lord Malton, 31 October 1741.

15 WWM, M7-19. Lady Malton to Lady Finch, 2 November 1741.
} 


\section{Marjorie Bloy}

continued with the blister and applied "ointment with flyes", apparently some sort of irritant potion, with no sign of strangury. Charles found her treatment "not near the pain he expected" and she was "full of hopes that he will rec[eiv]e great benefit from it". 16

Apart from his other troubles, one of Charles's knees had swollen but this had much abated since the application of the blisters which Lady Malton believed "must be acting upon the whole Mass of Blood" since it had "reached the remote part". She thought that Sir Edward Hulse's powders were too slow in taking effect although the boy took them very quietly. ${ }^{17}$ Sir Edward did not "apprehend any great danger from the Siziness [thickness] of Charles' blood"; Lady Malton thought that the condition was the cause of all the child's problems, which would not end until it was set to rights. At any rate, he was fit enough to go hunting. ${ }^{18}$ Charles continued in the same state of health. He slept well at night, ate more than his mother thought was good for him, and was able to exercise strenuously without tiring. He put on no weight though, and "as for them swellings at his throat, they are almost gone one day and rise the next". His mother did not expect a speedy recovery and "if the D[octo]rs think him in a good state of health now, I s[houl]d be glad to see him in a better". ${ }^{19} \mathrm{He}$ began to improve and by the end of November even she thought he was on the mend and gaining weight. ${ }^{20}$ Unfortunately, Lady Malton again had cause for concern over his health in January 1742 when he began to suffer from an intermittent hoarseness. ${ }^{21}$ Otherwise he was as well as one could expect, with no other complaints. ${ }^{22}$ It was not to last.

In May 1742 Charles and his mother were again in Bristol, taking the waters because he had been indisposed. Lady Malton thought the waters were doing them good because they were both being violently sick. ${ }^{23}$ However, Charles had had no dinner on 25 or 26 May and was hot, lazy, and inclined to stir, "from which I conclude he is not well, ... and therefore Intend to give him a gentle Vomit ... and to let him take his old Remedie the Salt Draughts for a few Daies which I dare say will set him quite to rights". ${ }^{24}$ By 29 May Dr Bourne had bled the boy "which succeeded very well but . . . found it [his blood] as bad as ever". The waters were not working "but there is a great deal for them to do which grant God they may effect". The weather had turned warm so Lady Malton had "shorn him . . . which has display'd a most scabby head and indeed several other untoward Blotches he has out upon other parts of his Body", which made her uneasy. ${ }^{25}$ The blotches on his head were not numerous "yet they made up in quality for so virulent a Corrosive Humour is not easily conceived without seeing it". The pustules on his body were of the same sort

${ }^{16}$ WWM, M7-17. Lady to Lord Malton, 4 November 1741.

17 WWM, M7-18. Lady to Lord Malton, 4 November 1741.

18 WWM, M7-16. Lady to Lord Malton, 7 November 1741.

19 WWM, M7-15. Lady to Lord Malton, 9 November 1741.

20 WWM, M7-22. Lady to Lord Malton, 25 November 1741.

${ }^{21}$ WWM, M7-1. Lady to Lord Malton, 25 January 1742.

22 WWM, M7-4. Lady to Lord Malton, 8 February 1742 and WWM, M7-9. Lady to Lord Malton, 22 February 1742.

23 WWM, M7-29. Lady to Lord Malton, 12 May 1742.

24 WWM, M7-35. Lady to Lord Malton, 26 May 1742.

25 WWM, M7-36. Lady to Lord Malton, 29 May 1742. 
and his mother intended to put plasters on them to prevent them from spreading. Charles was also feverish; his glands were swollen and his pulse was erratic "but out of compassion to you I must tell you that he is with me as Brisk and lively as you ever Saw him". Lady Malton had called in two eminent Bristol men, Dr Logan and $\mathrm{Mr}$ Pye, to treat the boy; Mr Pye prescribed "the Precipitate Per se" as the cure for the "hectic". Pye made it himself and said that it was the only remedy that would work. Clearly Charles was impatient to be cured because he told his mother to give him the medicine "to cure me which I am sure it will do or shoot me through the head at once". She thought that this attitude was "odd from one of his Age and [it] does not a little disturb" ${ }^{26}$ The blotches began to burst and indent but the doctor thought that all would be well in the end. ${ }^{27}$ Meanwhile, Charles was still losing weight even though "he had none to spare before" and he was inclined to be lazy which was not his natural turn. His father recommended some unknown cure which he called Gascoin's Powder - a dose of five grains made up with syrup into a pill — every night.

To make matters worse, the doctors disagreed about the treatment. "Dr Pye is Vehemently for the P. Per se, Dr Logan saies that it is a Medicine that may prove too rough in its operation for his Constitution \& therefore begs a tryal of Beazor mineral [gall stones from a goat] and Viper Broth". The Bristol water had not yet acted "because his case is of too obstinate a Nature" and Lady Malton herself was satisfied that since nothing else had worked to cure the boy, the time had come to try mercurials, even though she knew that they were "powerful and perhaps in some cases hazardous medicines". ${ }^{28}$ She wanted to see some remedy succeed but was "afraid of violent ones and at the same time vastly distrustfull [sic] of mild ones". It would appear that the "precipitate Per se", probably mercury-based, could be a kill-or-cure remedy. Her "terrors" did not arise from any immediate danger to her son, and her "perfect Knowledge" of his disorder convinced her that whatever remedies he took, the cure was in the hands of God. ${ }^{29}$

To add to Charles' disorders, on 12 June he developed a "very inflamed bad Eye ... the same Eye that ... he did not see so well of [as] the other . . . He sais [sic] that from that eye Alone he can Scarcely distinguish anything". The doctors suggested bathing the eye: Lady Malton knew that the "frightful symptoms" which were "shocking to behold" were a result of "the Same as produces all the rest of his complaints in whichever Shape they appear". ${ }^{30}$ The eye was very bloodshot and inflamed; the eyelid was swollen so he could hardly open it. The other eye was dull and "he had very little sight of it". ${ }^{31}$ By 14 June the eye problem had eased somewhat but Lady Malton could find no cause to attribute the improvement to any of the "cures". Charles was still being subjected to Bristol water, Beazor mineral, Viper broth, cinnabar and the precipitate per se. ${ }^{32}$ She decided to take the boy home to Wentworth because he was

\footnotetext{
${ }^{26}$ WWM, M7-38. Lady to Lord Malton, 1 June 1742.

27 WWM, M7-39. Lady to Lord Malton, 2 June 1742.

28 WWM, M7-41. Lady to Lord Malton, 5 June 1742.

29 WWM, M7-43. Lady to Lord Malton, 7 June 1742.

30 WWM, M7-45. Lady to Lord Malton, 12 June 1742.

${ }^{31}$ WWM, M7-56. Lady to Lord Malton, undated: 12 June? 1742.

32 WWM, M7-46. Lady to Lord Malton, 14 June? 1742.
} 


\section{Marjorie Bloy}

more likely to recover there than anywhere else. ${ }^{33}$ He still ate and slept well and was "pretty cheerful but his looks are bitter bad still. The flesh he lost in the Accidental Feavour he has not Recover'd and his complexion is of the most sickly sort his hands of the same Hue his legs are tollerable [sic] well". 34

They returned to Wentworth in short stages and by 6 September Higham was "perfectly recovered . . . after the long and successful Care that Lady Malton has taken" of him. ${ }^{35}$ In May 1743 he was inoculated against smallpox and made a perfect recovery after which he caught cold "by stripping when He was hot". ${ }^{36}$ Lord Higham does not seem to have been seriously ill after that until, at the age of 19 , he undertook his Grand Tour in 1749.

In July 1750 , by then Lord Malton, he had cause to consult Nicolò Scanagati in Padua for the treatment of gonorrhoea. Scanagati produced a lengthy medical report of Malton's treatment, presumably for his English doctor's enlightenment. ${ }^{37}$ The initial treatment was an "electuary, consisting of three ounces of emollient, three drams of powdered jalap, a half [dram] of purified nitre, bound together with lemon juice taken twice a day". The result was satisfactory: “The dark greenish poison was oozing slowly from his penis, which was all contracted and the sharp and constant pain extended from the perineum up to the urinary bladder, producing small swellings now in this place, now in that." There was a fierce burning sensation in the glands, which prevented him from sleeping. Because of this, it seemed reasonable to bathe that part in tepid water and milk, and to apply poultices to the areas affected by swelling and contractions, together with cold drinks and a few grains of laudanum at night.

Malton was blooded regularly besides being given purgatives; the treatment then moved on to the administration of mercury, both internal and on the gums, since it was widely believed at the time that gonorrhoea and syphilis were steps of the same disease, "the Venereal". Scanagati at this point ruled out the suggestion of syphilitic chancre because Malton's urine was fine and light with a pungent odour. Scanagati did ask if Malton had previously ever had a similar peculiarity of his urine. Malton replied that when he was very young and still inexperienced sexually, for some time following a fever he had had the same unusual urine, and indeed that on one occasion this symptom coincided with certain tumours on the testicles. It was only by chance that he had not had recourse to surgery, the reason being that he was also afflicted with a throat infection - to which he was prone-and therefore had his vein opened four times. Thereupon the inflammation subsided, and equally the tumours and sediment disappeared.

He told me that as a youth he had sometimes experienced some difficulty and a burning sensation when urinating, which subsided when his blood was let and with the application of poultices. I observed that from time to time his face and body were covered with purplish spots, which, having produced a little fluid, would disappearas indeed happened in the course of the cure, at the end of which his face was entirely

${ }^{33}$ WWM, M7-47. Lady to Lord Malton, 15 June 1742.

34 WWM, M7-48. Lady to Lord Malton, 16 June 1742.

35 WWM, M2-104/5. Lady Finch to Lady Malton, 6 September 1742.

${ }^{36}$ WWM, M2-135. Lady Finch to Malton, 18 June 1742.

${ }^{37}$ WWM, R170-20. Nicolò Scanagati's report. 


\section{An eighteenth-century Prime Minister's illness}

free from these spots. From this observation, it seemed to me simple to deduce both the original cause and the more immediate cause of the said sediment: namely a natural complexion of humours which are exacerbated by muriatic [i.e., acidic] sourness, together with the marked inflammation of the blood and the motion of the contracted poison.

Scanagati then recommended the continuation of the electuary made of emollient, guaiacum resin, balsam, rhubarb, and nitre.

What does all this add up to in terms of diagnosis? The early illness is a mystery. Did he have an inguinal hernia; or perhaps mumps or epididymitis? His was a childless marriage. He seems to have been too fit for the illness to have been rheumatic fever. Cystitis was not uncommon and this could certainly lead to "strangury". Perhaps Rockingham suffered from a congenital defect of his urinogenitary system which would result in recurrent attacks of cystitis and might cause long-term damage to the urinary tract and eventual destruction of the kidneys, precipitating sudden and unexpected death.

Another possibility might be diabetes. Rockingham had a urinary infection and certainly suffered from recurrent skin infections, although it appears from Scanagati's report that these cleared up when mercury was administered.

Certainly the marquis complained often about pains in his side and stomach and made no secret of his "old complaint". He was noticeably less physically active as he moved into his thirties and only occasionally exerted himself by riding any distance, even though he had enjoyed hunting when he was younger. He found the pains caused by his "old complaint" made him feel so ill that he was unable to concentrate on "any Manner of Business" and on occasion it seemed likely to prevent him from attending Parliament. ${ }^{38} \mathrm{He}$ may well have suffered from a problem with gallstones from an early age. ${ }^{39} \mathrm{He}$ appears to have suffered from a nervous disorder which manifested itself in severe palpitations, trembling, and other types of physical discomforts such as boils and headaches with which he was frequently afflicted. ${ }^{40} \mathrm{He}$ probably had constipation too, since he was always dosing himself with purgatives. In fact in April 1772 the Duke of Richmond decided that Rockingham's real problem was a "surfeit of physick"41 although Edmund Burke noted in June 1772 that the marquis had had a long and severe illness. ${ }^{42}$ Whatever his many and varied ailments, Rockingham survived until he was 52 in spite of the attentions of both doctors and quacks and that, for the mid-eighteenth century, was a good age. The mystery still remains, however. Contemporary opinion had it that he died of pneumonia but it must have struck

\footnotetext{
38 WWM, R153-1. Rockingham to Burke, 31 October 1767; WWM, R1-1238. Rockingham to Dowdeswell, 20 October 1769; WWM, R1-1928. Rockingham to Savile, September 1780.

${ }^{39}$ Ross J. S. Hoffman, The Marquis. A study of Lord Rockingham, 1730-1782, New York, Fordham University Press, 1973, p. 35. This is the only recent biography of the second Marquis of Rockingham, and does not deal with his illnesses. Although he does not give the source of his information, Hoffman asserts that Rockingham was in Bath between March and August 1761 suffering from gallstones. The marquis would then have been 31 years old.

${ }^{40}$ Historical Manuscripts Commission, Lindley Wood, p. 184.

41 WWM, R1-1403. Richmond to Rockingham, 26 April 1772.

42 Burke to James de Lancey, 30 June 1772. The correspondence of Edmund Burke, vol. 2, ed. T. W. Copeland and others, Cambridge University Press, 1958-1978, p. 311.
} 


\section{Marjorie Bloy}

suddenly: it was only two weeks from him "recovering" to dying. Another almost contemporary account of the marquis's death came from the Earl of Albemarle. He noted that Rockingham had "for some time past been afflicted with water on the chest: and to this well-known malady was superadded the then novel disease of influenza". ${ }^{43}$ This conceivably could be an uninformed account, handed down orally by surviving members of the marquis's family, of emphysema. More fascinating than the diagnosis of the cause of death, however, is - what was wrong with him during his lifetime? Or is it yet another example of the "English disease": hypochondria?

${ }^{43}$ Albemarle, George Thomas, Earl of, Memoirs of the Marquis of Rockingham and his contemporaries, London, Richard Bentley, 2 vols., 1852, vol. 2, p. 483. This is the only contemporary work concerning Rockingham, but does not mention his early life and illnesses. 